\begin{tabular}{|l|l|l||}
\hline \multicolumn{2}{|c|}{ PublisherInfo } \\
\hline \hline PublisherName & $:$ & BioMed Central \\
\hline \hline PublisherLocation & $:$ & London \\
\hline \hline PublisherImprintName & $:$ & BioMed Central \\
\hline \hline
\end{tabular}

\title{
Malaria mosquito resistance revealed
}

\begin{tabular}{|l|l|l||}
\hline \multicolumn{2}{|c|}{ ArticleInfo } \\
\hline \hline ArticleID & $:$ & 4768 \\
\hline \hline ArticleDOI & $:$ & $10.1186 /$ gb-spotlight-20030508-01 \\
\hline \hline ArticleCitationID & $:$ & spotlight-20030508-01 \\
\hline \hline ArticleSequenceNumber & $:$ & 120 \\
\hline \hline ArticleCategory & $:$ & Research news \\
\hline ArticleFirstPage & $:$ & 1 \\
\hline \hline ArticleLastPage & $:$ & 2 \\
\hline \hline & & RegistrationDate : 2003-5-8 \\
\hline ArticleHistory & $:$ & OnlineDate \\
\hline \hline ArticleCopyright & $:$ & BioMed Central Ltd2003-5-8 \\
\hline \hline ArticleGrants & $:$ & \\
\hline \hline ArticleContext & $:$ & 130594411 \\
\hline \hline
\end{tabular}




\section{Cathy Holding}

Email: cholding@hgmp.mrc.ac.uk

Malaria causes more than a million deaths a year in Africa alone. Attempts to combat the disease have been frustrated on two fronts: acquisition of resistance to antimalarial agents by the parasite itself and acquisition of resistance to insecticides by its mosquito vector, Anopheles gambiae. In the May 8 Nature, Mylene Weill and colleagues at the Institut des Sciences et de l'Evolution, Montpelier, France, identify a mechanism of resistance to organophosphate insecticides, paving the way for a renewed attack on the most common resistant strains (Nature, 423:136-137, May 8, 2003).

Weill et al. compared the sequence of an organophosphate target (the acetylcholinesterase gene ace-1) in a resistant and susceptible strain of the mosquito Culex pipiens - vector of the West Nile virus. Analysis revealed one of 27 nucleotide differences resulting in a G119S substitution that they localized to a position near the active site of the enzyme. Further analysis confirmed the coincidence of this amino acid substitution with insecticide resistance in several other strains of the same species, and it was also identified in the ace- 1 of a resistant strain of $A$. gambiae. In addition, they showed that this amino acid substitution has arisen independently at least three times in mosquito species.

"The development of new insecticides that can specifically inhibit the G119S mutant form of acetylcholinestease-1 will be crucial in overcoming the spread of resistance," conclude the authors.

\section{References}

1. New trends in anti-malarial agents.

2. Heterologous expression of four glutathione transferase genes genetically linked to a major insecticide resistance locus, from the malaria vector Anopheles gambiae.

3. Nature, [http://www.nature.com/nature]

4. Institut des Sciences et de l'Evolution, [http://www.isem.univ-montp2.fr]

This PDF file was created after publication. 